\title{
Effects of tobacco smoking on cancer and cardiovascular disease in urban black South Africans
}

\author{
L Stein', MI Urban', M Weber', P Ruff', M Hale', B Donde ${ }^{5}$, M Patel ${ }^{6}$ and F Sitas ${ }^{*}, 2$ \\ 'MRC/NHLS/Wits Cancer Epidemiology Research Group, National Health Laboratory Service, PO Box 1038, Johannesburg 2000, South Africa; ${ }^{2}$ Cancer \\ Epidemiology Research Unit, The Cancer Council NSW, PO Box 572, Kings Cross 1340, Australia; ${ }^{3}$ Division of Medical Oncology, Department of \\ Medicine, Johannesburg Hospital and the University of the Witwatersrand, 7 York Road, Parktown, Johannesburg 2193, South Africa; ${ }^{4}$ Department of \\ Anatomical Pathology, Chris Hani Baragwanath Laboratory, School of Pathology, University of the Witwatersrand, and National Health Laboratory Service, \\ PO Box 1038, Johannesburg 2000, South Africa; ${ }^{5}$ Division of Radiation Oncology, Department of Medicine, Johannesburg Hospital and the University of \\ the Witwatersrand, 7 York Road, Parktown, Johannesburg 2193, South Africa; ${ }^{6}$ Clinical Haematology Division, Department of Medicine, Chris Hani \\ Baragwanath Hospital and the University of the Witwatersrand, 7 York Road, Parktown, Johannesburg 2193, South Africa
}

Demographic and lifestyle information from 9690 black patients diagnosed with cancer or cardiovascular disease was collected in an ongoing case-control study in Johannesburg, South Africa. Compared to never smokers, the odds ratio (OR) for lung cancer among current smokers was 16.3 (95\% confidence interval $(\mathrm{Cl}), 9.6-27.6)$ for men and $6.4(95 \% \mathrm{Cl}, 4.0-10.4)$ for women. The corresponding OR for other smoking-related cancers was 4.6 (95\% Cl, 3.7-5.7) among men and $1.9(95 \% \mathrm{Cl}, 1.6-2.2)$ among women, and for cardiovascular disease, 3.4 (95\% Cl, 2. I -5.4) among men and 1.5 (95\% Cl, I.I - 2.I) among women. Risks were higher among smokers than former smokers, and all risk estimates increased with increasing levels of smoking duration and intensity. Non-electric domestic fuel was associated with approximately $60 \%$ increase in the risk of smoking-related cancer, but not cardiovascular disease. Risks for cancers of cervix, oesophagus, oral cavity/pharynx, stomach, larynx, pancreas and anogenital region, as well as squamous cell carcinoma of skin were all significantly higher among current than never-smokers, with ORs ranging from 1.5 for cervix $(95 \% \mathrm{Cl}, 1.2-1.8)$ to 14.7 for larynx $(95 \% \mathrm{Cl}, 7.2-30)$. The risks of tobacco-related disease reported here are similar to that currently observed in Western countries, even though cigarette consumption is relatively low in this population.

British Journal of Cancer (2008) 98, I586- 1592. doi: I0.1038/sj.bjc.6604303 www.bjcancer.com

Published online 25 March 2008

(c) 2008 Cancer Research UK

Keywords: tobacco smoking; neoplasms; cardiovascular disease; case-control study; South Africa; domestic fuel

Certain findings from an ongoing case-control study, which began in 1995, of lifestyle and infectious risk factors for cancer among the black African community of wider Johannesburg, South Africa have been reported (Sitas et al, 1999, 2000, 2007; Pacella-Norman et al, 2002; Wojcicki et al, 2003, 2004; Berrington et al, 2006). These include elevated risks associated with tobacco smoking and cancers of the oesophagus, lung, oral cavity and larynx (PacellaNorman et al, 2002) that were broadly consistent with international findings (Vineis et al, 2004). The sample size has doubled since the 2002 report, allowing estimates of smoking-related risks of less common cancers (Vineis et al, 2004).

The study began just after the implementation of South Africa's first tobacco control legislation and since then both smoking prevalence and overall tobacco consumption has decreased dramatically. In 1995, smoking prevalence among adults was $30.2 \%$ and by 2004 it fell to $24.1 \%$ (Saloojee, 2006), while in the 10 years to 2001 cigarette consumption had decreased by one-third (Saloojee, 2006). The black African community of South Africa, which accounts for almost two-thirds of the population, has the lowest levels of smoking prevalence within the country $(22.7 \%$ in

*Correspondence: Dr F Sitas; E-mail: freddys@nswcc.org.au Received 22 November 2007; revised 4 February 2008; accepted II February 2008; published online 25 March 2008
2000, down from $28.1 \%$ in 1993) (van Walbeek, 2002a) and consumes the least amount of cigarettes (averaging 7 per day in 1998) (Steyn et al, 2002). This partly reflects cultural beliefs and partly poverty on which the excise tax on tobacco has had the greatest effect (van Walbeek, 2002b). The smoking-related cancers of oesophagus, lung, larynx, stomach and cervix remain leading cancer types among black South Africans (Norman et al, 2006).

The aim of this analysis was to provide local estimates of the risks associated with smoking for smoking-related cancers and cardiovascular disease, and to explore the effects of duration, intensity and cessation of smoking on these estimates. Because tobacco smoking is associated with several squamous cell cancers (e.g., oral cavity, oesophagus, cervix), we also investigated the squamous cell cancer of the skin (SCC skin), as well as anogenital sites (other than cervix), in relation to smoking.

\section{MATERIALS AND METHODS}

The Johannesburg Cancer Case Control Study is based in the three main public referral hospitals of Johannesburg and Soweto. General methods have been described elsewhere (Sitas et al, 1999). In addition, in 1998-2001, patients presenting with cardiovascular diseases were included. The study was approved by the University of the Witwatersrand Human Research Ethics 
Cancer and cardiovascular disease associated with smoking

Committee (Medical). At the time of analysis, there were 9690 patients 18 years old or older who had a newly diagnosed cancer or a cardiovascular disease and who were interviewed between March 1995 and June 2004.

In our first series of analyses, the data were arranged into four groups, a control group and three different 'disease' case groups. The control group comprised data from 4059 patients who had cancer thought not to be associated with tobacco smoking, and the three case groups comprised patients with (1) lung cancer (423), (2) other cancers known to be associated with tobacco smoking 'smoking-related' (3961), or (3) a cardiovascular disease (716) (Table 1). In a second series of analyses, risks associated with smoking were calculated separately for cancers included in the 'smoking-related' group (where $n>10$ ), as well as anogenital cancers and SCC skin (Table 1).

Altogether, 287 cancer cases were excluded from all analyses because either the cancer was at a secondary site (C77) or the number of cases was small, that is, cancers of the heart (C38), gall bladder (C23), skin (C44 - not SCC), mesothelioma (C45), unspecified genital cancers (C57, C58) and unspecified cancers of the digestive system (C24, C26).

The first series of analyses were stratified by gender and patients were grouped according to particular risk factors, that is, age (18$34,35-54,55-98)$, education $(0-5,6-9,9+$ years), type of domestic cooking fuel (electrical or non-electrical - i.e., wood, charcoal, coal, anthracite, paraffin, or gas), and tobacco smoking status (never, former, current). Since some patients may have given up smoking due to their illness, those who smoked within 5 years of the interview date were classified as current smokers, while those who stopped smoking before this time were classified as former smokers. Never smokers were participants who answered 'Never' to the question, 'Have you ever smoked cigarettes or a pipe regularly?' Patients were also grouped according to how much tobacco they smoked per day $(0,1-14,15 \mathrm{~g}+$ assuming weights of $1 \mathrm{~g}$ for commercial cigarettes, $1 \mathrm{~g}$ for hand-rolled cigarettes, and a conservative $1 \mathrm{~g}$ per pipeful), the number of years they smoked $(0$, $1-20,21+$ ) and how many 'pack-years' they smoked (i.e., number of packs smoked per day multiplied by the number of years smoked; $0,1-10,11-20,21-30,31+)$. A 'pack' was assumed to contain 20 cigarettes (or 20 hand-rolled cigarettes or 20 pipefuls). As the number of former smokers who smoked more than 30 pack-years was insufficient for analysis, the highest level of pack-years calculated for former smokers was 21 or more.

In the second series of analyses, the data were grouped according to cancer site and distributed by smoking status (never, former, current), but were not stratified by gender due to small numbers of most cancers.

\section{Statistical analyses}

Relative risks for the association of each risk factor and cancer/ cardiovascular disease were estimated by using the odds ratios (ORs) derived from unconditional, unmatched multiple logistic regression. A separate term was used for each adjustment factor in the model, and these included: age, education level, and type of domestic cooking fuel. The risk estimates for each individual cancer site in the second series of analyses were also adjusted for gender and alcohol intake (ever/never). A $\chi^{2}$ test for trend/ heterogeneity, adjusting for all other stratification levels, was used to test for significance across exposure levels. Missing variables were added to all regression models as a separate term and are presented in tables as 'unspecified'.

\section{RESULTS}

The study population was primarily female $(65 \%)$ with a median age of 52. The median education level was 7 years of schooling
Table I Diseases grouped for analysis

\begin{tabular}{|c|c|c|}
\hline Site & ICD-IO & $n$ \\
\hline \multicolumn{3}{|l|}{ Smoking-unrelated cancers } \\
\hline Breast & C50 & 1442 \\
\hline Prostate & C6I & 402 \\
\hline Kaposi's sarcoma & C46 & 384 \\
\hline Colon & $\mathrm{Cl} 8-\mathrm{C} 20$ & 333 \\
\hline Non-Hodgkin's lymphoma & $\mathrm{C} 82, \mathrm{C} 83$ & 239 \\
\hline Endometrium & $\mathrm{C} 54, \mathrm{C} 55$ & 199 \\
\hline Myeloma & C90 & 197 \\
\hline Ovaries & $\mathrm{C} 56$ & 196 \\
\hline Hodgkin's disease & $\mathrm{C} 81$ & 156 \\
\hline Leukaemia (not myeloid) & C9I-C95 & 116 \\
\hline Soft tissue sarcoma & C49 & 105 \\
\hline Bone & C40, C4I & 71 \\
\hline Melanoma & C43 & 58 \\
\hline Thyroid & $\mathrm{C} 73$ & 44 \\
\hline Brain & $\mathrm{C7I}$ & 30 \\
\hline Endocrine gland & $\mathrm{C} 75$ & 27 \\
\hline Eye and adnexa & C69 & 13 \\
\hline Meninges & C70 & 13 \\
\hline Testes & C62 & 9 \\
\hline Peritoneum and retroperitoneum & $\mathrm{C} 48$ & 7 \\
\hline Peripheral nerves and ANS & C47 & 5 \\
\hline CNS & $\mathrm{C} 72$ & 5 \\
\hline Thymus & C37 & 4 \\
\hline Small intestine & $\mathrm{Cl}$ & 3 \\
\hline Unspecified lymphoid & C96 & \\
\hline Lung cancer & $\mathrm{C} 33, \mathrm{C} 34$ & 423 \\
\hline $\begin{array}{l}\text { Squamous cell carcinoma (SCC) } \\
\text { of the skin }\end{array}$ & $\begin{array}{l}\text { C44 (M8070-8076, M8560, } \\
\text { M808I, M805I-2) }\end{array}$ & 70 \\
\hline \multicolumn{3}{|l|}{ Smoking-related cancers } \\
\hline Cervix & C53 & 1885 \\
\hline Oesophagus & $\mathrm{Cl} 5$ & 901 \\
\hline Oral cavity and pharynx & $\mathrm{COO}-\mathrm{ClO}, \mathrm{Cl} 2-\mathrm{Cl} 4$ & 369 \\
\hline Myeloid leukaemia & C92 & 213 \\
\hline Stomach & $\mathrm{Cl} 6$ & 162 \\
\hline Larynx & $\mathrm{C} 32$ & 139 \\
\hline Liver & $\mathrm{C} 22$ & 88 \\
\hline Nasal cavity and nasopharynx & $\mathrm{Cl}, \mathrm{C} 30, \mathrm{C} 31$ & 71 \\
\hline Pancreas & $\mathrm{C} 25$ & 53 \\
\hline Bladder & C67 & 47 \\
\hline Kidney & C64 & 25 \\
\hline Unspecified urinary & C68 & 7 \\
\hline Ureter & C66 & \\
\hline \multicolumn{3}{|l|}{ Anogenital cancers } \\
\hline Vulva & C5I & 107 \\
\hline Anus & $\mathrm{C} 20$ & 31 \\
\hline Penis & C60 & 22 \\
\hline Vagina & C52 & 14 \\
\hline \multicolumn{3}{|l|}{ Cardiovascular diseases } \\
\hline Hypertention & $110-115$ & 266 \\
\hline Stroke & 164 & 176 \\
\hline Congestive heart failure & 150 & $14 \mid$ \\
\hline Pulmonary heart disease & 126,127 & 40 \\
\hline Cerebral infarction & 163 & 37 \\
\hline Cardiovascular disease & 151 & 29 \\
\hline Ischaemic heart disease & 124,125 & 10 \\
\hline Other vascular diseases & $105-109,120,121,131,134$ & \\
\hline & $140,142,161,167,180$ & 17 \\
\hline
\end{tabular}

(primary school). Many (30\%) participants reported current use of non-electric domestic cooking fuel and $41 \%$ stated that they had ever smoked, of whom just over one-third had quit 5 or more years prior to interview. Thus, for the purposes of our analyses, $26.6 \%$ of the study population were classified as current smokers (13\% of 
women and $52 \%$ of men), $14 \%$ were former smokers ( $9 \%$ of all women and $24 \%$ of all men), and $59.4 \%$ as never smokers ( $78 \%$ of women and $23 \%$ of men).

Subjects are tabulated by age, education, smoking status and type of domestic cooking fuel in Table 2. Patients with lung cancer were primarily male (79\%), over the age of $54(60 \%)$, 'ever' smokers $(85 \%)$, completed a maximum of only 5 years of schooling $(68 \%)$, and used electricity for cooking (69\%). Patients with a smoking-related cancer (other than lung) were primarily male (66\%) with ages spread evenly across the $34-54(46 \%)$ and 54-98 age groups (47\%), 'never' smokers (54\%), were schooled for a maximum of 5 years (64\%), and $64 \%$ used electricity for cooking. Patients with cardiovascular disease were mainly female (78\%), with ages spread evenly across the 34-54 (44\%) and 54-98 (42\%) age groups, with $61 \%$ never smokers, $49 \%$ with a maximum of 5 years education, and $75 \%$ used electricity for cooking.

For both sexes, lung cancer was significantly associated with age and smoking status (Table 2). There was a significant trend in lung cancer risk increasing with age, and with former smokers having a two-fold lower risk than current smokers. Education and type of domestic cooking fuel were associated with lung cancer among men only. Specifically, increased levels of education were associated with a significantly lower risk of lung cancer among men, and lung cancer risk was higher among men who used nonelectric cooking fuel.

Smoking-related cancer was significantly associated with age, education, smoking status and type of cooking fuel for both sexes (Table 2). Significant trends in the risk of smoking-related cancer included lower risks among those with higher levels of education, lower risks among former than current smokers, and higher risks among those without electric cooking facilities. Among men, there was a significant trend in the risk of smoking-related cancer increasing with age, but this was not significant among women.

Cardiovascular disease was associated with smoking status for both sexes, with significant lower risk estimates among former smokers than current smokers. Education and domestic cooking fuel were not associated with cardiovascular disease. Age was associated with cardiovascular disease only among men, with participants in the 35-54 years age group at a higher risk than those in the 18-34 years age group.

The use of non-electric domestic cooking fuel was significantly associated with lung cancer (men only) and other smoking-related cancers, but not cardiovascular disease. However, the risk of disease associated with smoking and cooking fuel increased when these two factors were combined. Specifically, 'ever' smokers of both sexes increased their risk of a smoking-related cancer or lung cancer by approximately $60 \%$ if they also used non-electric cooking fuel; ever smokers among men increased their risk of a cardiovascular disease by $30 \%$. However, among women, this fuel did not increase cardiovascular disease risk above that of ever smokers (Table 2).

The distribution of cases and controls according to number of years smoked, amount of tobacco smoked per day and number of pack-years is shown in Table 3, and each of these variables were significantly associated with all three case groups. There were significant trends across exposure levels for all groups, where risk estimates increased with greater numbers of years smoked, greater amounts of tobacco smoked per day, and with increasing packyears. Men had higher risks in all the three disease groups than women in terms of all smoking variables analysed. Risks for current smokers across all exposure levels were consistently higher than for former smokers.

The association between smoking and site-specific cancers is presented in Figure 1. Cancers of cervix, stomach, pancreas, oesophagus, anogenital region (excluding cervix), oral cavity/ pharynx, lung, larynx, and SCC skin were all significantly associated with current smoking (Figure 1A). Sites among current smokers that showed nonsignificant elevated risks included the bladder, liver, kidney, and nasal cavity/nasopharynx cancers. In former smokers (Figure 1B), the relative risks were 1.3-3.3 times lower than for current smokers, except for myeloid leukaemia where the risk was significantly higher for former smokers. Relative risk estimates for former smokers remained significantly above those of never smokers for cancers of the stomach, anogenital region, oesophagus, oral cavity/pharynx, lung and larynx, and for myeloid leukaemia.

\section{DISCUSSION}

Using a hospital-based sample of black African patients in Johannesburg, South Africa, this study found elevated risks associated with smoking and cancers of the lung, other smokingrelated cancers (i.e., cancers of the cervix, oesophagus, oral cavity and pharynx, stomach, larynx, liver, nasal cavity and nasopharynx, pancreas, bladder, kidney and other urinary sites, and myeloid leukaemia, pooled), and cardiovascular disease, which are similar to international findings (Vineis et al, 2004). All smoking-related risk estimates increased with both the number of years smoked and the amounts smoked daily. All risk estimates were significantly lower among former smokers, and were higher overall for men. The use of non-electric domestic cooking fuel was associated with increased risks of lung and other smoking-related cancers, but not of cardiovascular disease. When combined with smoking, the risk of cardiovascular disease was also significantly associated with its use in men, but not in women, and the risk of lung and other smoking-related cancers was further increased for both sexes.

In 2002, the first report on tobacco-related cancer risk from this study was published, comprising just over 4200 participants who were interviewed between 1995 and 1999 (Pacella-Norman et al, 2002). With our larger sample size, the risks associated with tobacco smoking reported here are slightly different. Specifically, the relative risk of lung cancer among smokers is now estimated to be higher for men and lower for women when compared to the original report. However, with the increase in the number of lung cancer cases (increased from 110 to 333 in men and 41 to 90 in women), the risk estimates are now more precise.

The 2002 report also investigated an association between non-electric domestic fuel and cancer. With a very small sample size $(n=6 / 7)$, it was found that use of paraffin ' 20 years ago' for heating was associated with lung cancer in men and oesophageal cancer in women. In the current analysis, we pooled the use of non-electric fuels (including paraffin) and found that a 'current' use of non-electric fuel for cooking was associated with a $60 \%$ increase in the odds of a smoking-related cancer for both sexes. Non-electric cooking fuel also increased the risk of lung cancer alone by about $60 \%$ among men but not in women. Of those reporting a current use of non-electric cooking fuel, $37 \%$ used coal, $24 \%$ used wood, and $34 \%$ used paraffin. The rest were users of gas $(4.9 \%)$, charcoal $(0.2 \%)$, or anthracite $(0.03 \%)$. Residential stoves that use biomass fuels or coal produce extremely high levels of indoor air pollution in the form of particulate matter, nitrogen dioxide, carbon monoxide, and in particular, of carcinogenic polynuclear aromatic compounds such as benzo(a)pyrene, benzene and 1,3-butadiene (IARC, 1985; Cohen et al, 2004). Particulate air pollution has been estimated to account for $5 \%$ of lung cancer deaths worldwide (Cohen et al, 2004), so a significant association of domestic cooking fuel and smoking-related cancers in this study is not surprising.

The larger size of the current study allowed for examination of smoking duration, intensity and cessation. Most men with lung cancer were current smokers who had smoked for over 20 years, and their risk of lung cancer was four-fold higher than smokers of shorter durations. In contrast, most women with lung cancer reported being 'never smokers'. Nevertheless, current female 
Table 2 Risk of lung cancer, other smoking-related cancers, and cardiovascular disease distributed by demographic and lifestyle factors ${ }^{\mathrm{a}}$

\begin{tabular}{|c|c|c|c|c|c|c|c|c|c|c|c|c|c|c|c|c|c|c|c|c|c|c|c|c|c|c|}
\hline \multirow[b]{4}{*}{ Risk factor } & \multicolumn{2}{|c|}{ Controls ${ }^{\mathbf{b}}$} & \multicolumn{8}{|c|}{ Lung Cancer } & \multicolumn{8}{|c|}{ Smoking-related cancer ${ }^{b}$} & \multicolumn{8}{|c|}{ Cardiovascular disease $^{c}$} \\
\hline & \multirow{3}{*}{$\begin{array}{c}\text { Male } \\
n=\begin{array}{c}\mid 383 \\
n\end{array}\end{array}$} & \multirow{3}{*}{$\begin{array}{c}\text { Female } \\
\begin{array}{c}n=2676 \\
n\end{array}\end{array}$} & \multicolumn{4}{|c|}{ Male } & \multicolumn{4}{|c|}{ Female } & \multicolumn{4}{|c|}{ Male } & \multicolumn{4}{|c|}{ Female } & \multicolumn{4}{|c|}{ Male } & \multicolumn{4}{|c|}{ Female } \\
\hline & & & \multicolumn{2}{|c|}{$n=333$} & \multicolumn{2}{|c|}{$95 \% \mathrm{Cl}$} & \multicolumn{2}{|c|}{$n=90$} & \multicolumn{2}{|c|}{$95 \% \mathrm{Cl}$} & \multicolumn{2}{|c|}{$n=1330$} & \multicolumn{2}{|c|}{$95 \% \mathrm{Cl}$} & \multicolumn{2}{|c|}{$n=2631$} & \multicolumn{2}{|c|}{$95 \% \mathrm{Cl}$} & $n=$ & 159 & $95 \% \mathrm{C}$ & & $n=$ & 557 & $95 \% \mathrm{Cl}$ & \\
\hline & & & $n$ & OR & LCI & UCI & $n$ & OR & LCI & UCl & $n$ & OR & LCI & UCI & $n$ & OR & LCI & UCI & $n$ & OR & LCI & UCI & $n$ & OR & LCI & u \\
\hline Age & & & & & & & & & & & & & & & & & & & & & & & & & & \\
\hline $18-34$ & 253 & 412 & 5 & 1.0 & Referent & & 2 & 1.0 & Referent & & 90 & 1.0 & Referent & & 213 & 1.0 & Referent & & 22 & 1.0 & Referent & & 77 & 1.0 & Referent & \\
\hline $35-54$ & 478 & 1212 & 136 & 12.5 & 5.0 & 31.4 & 27 & 2.8 & 0.6 & 12.1 & 530 & 2.4 & 1.8 & 3.3 & 1283 & 1.5 & 1.2 & 1.8 & 88 & 2.0 & 1.2 & 3.42 & 228 & 0.8 & & \\
\hline $\begin{array}{l}55-98 \\
\chi^{2}(P \text { trend })\end{array}$ & 650 & 1050 & 192 & $\begin{array}{l}15.4 \\
35.0\end{array}$ & $\begin{array}{l}6.1 \\
(<0.0001)\end{array}$ & 38.7 & 61 & $\begin{array}{r}7.1 \\
19.2\end{array}$ & $\begin{array}{l}1.7 \\
(<0.0001)\end{array}$ & 30.3 & 710 & $\begin{array}{r}2.5 \\
23.2\end{array}$ & $\begin{array}{l}1.9 \\
(<0.0001)\end{array}$ & 3.4 & 1134 & $\begin{array}{l}1.4 \\
2.7\end{array}$ & $\begin{array}{l}1.1 \\
(0.10)\end{array}$ & 1.7 & 49 & $\begin{array}{l}0.8 \\
2.1\end{array}$ & $\begin{array}{l}0.4 \\
(0.15)\end{array}$ & 1.52 & 252 & $\begin{array}{l}1.0 \\
0.5\end{array}$ & $\begin{array}{l}0.7 \\
(0.50)\end{array}$ & \\
\hline Unspecified & 2 & 2 & 0 & - & - & - & 0 & - & - & - & 0 & - & - & - & 1 & - & - & - & 0 & - & - & - & 0 & - & - & \\
\hline Education (years) & & & & & & & & & & & & & & & & & & & & & & & & & & \\
\hline $0-5$ & 761 & 1317 & 226 & 1.0 & Referent & & 61 & 1.0 & Referent & & 848 & 1.0 & Referent & & 1683 & 1.0 & Referent & & 66 & 1.0 & Referent & & 287 & 1.0 & Referent & \\
\hline $6-8$ & 371 & 888 & 87 & 0.9 & 0.7 & 1.2 & 27 & 1.1 & 0.7 & 1.8 & 352 & 0.9 & 0.8 & 1.1 & 728 & 0.8 & 0.7 & 0.9 & 45 & 1.2 & 0.8 & $1.92 \mathrm{r}=$ & 201 & 1.1 & 0.9 & \\
\hline $\begin{array}{l}9+ \\
\chi^{2}(P \text { trend })\end{array}$ & 243 & 462 & 19 & $\begin{array}{l}0.5 \\
5.4\end{array}$ & $\begin{array}{l}0.3 \\
(0.02)\end{array}$ & 0.8 & 2 & $\begin{array}{l}0.3 \\
1.3\end{array}$ & $\begin{array}{l}0.1 \\
(0.26)\end{array}$ & 1.2 & 121 & $\begin{array}{l}0.7 \\
4.6\end{array}$ & $\begin{array}{l}0.5 \\
(0.03)\end{array}$ & 0.9 & 189 & $\begin{array}{r}0.5 \\
59.8\end{array}$ & $\begin{array}{l}0.4 \\
(<0.000 I)\end{array}$ & 0.6 & 27 & $\begin{array}{l}1.2 \\
0.7\end{array}$ & $\begin{array}{l}0.7 \\
(0.41)\end{array}$ & 2.1 & 67 & $\begin{array}{l}0.7 \\
1.4\end{array}$ & $\begin{array}{l}0.5 \\
(0.24)\end{array}$ & \\
\hline Unspecified & 8 & 9 & 1 & 0.8 & 0.1 & 8.0 & 0 & - & - & - & 9 & 1.6 & 0.6 & 4.8 & 31 & 3.1 & 1.5 & 6.6 & 21 & 6.1 & 1.0 & 36.4 & 2 & 1.1 & 0.2 & 5.1 \\
\hline Smokir & & & & & & & & & & & & & & & & & & & & & & & & & & \\
\hline $\mathrm{Nev}$ & 528 & 2264 & 16 & 1.0 & Referent & & 46 & 1.0 & Referent & & 176 & 1.0 & Referent & & 1970 & 1.0 & Referent & & 25 & 1.0 & Referent & & 412 & 1.0 & Referent & \\
\hline Former & 338 & 167 & 83 & 7.2 & 4.1 & 12.6 & 12 & 2.6 & 1.3 & 5.1 & 344 & 2.8 & 2.2 & 3.5 & 235 & 1.4 & 1.1 & 1.8 & 23 & 1.6 & 0.9 & 2.8 & 82 & 2.6 & 1.9 & \\
\hline $\begin{array}{l}\chi^{2}(P \text { trend }) \\
\text { Ever }\end{array}$ & 851 & 394 & 317 & $\begin{array}{r}142.4 \\
12.2\end{array}$ & 7.3 & 20.6 & 44 & $\begin{array}{r}5.2 \\
4.6\end{array}$ & 3.0 & 7.2 & 1152 & 3.9 & 3.2 & 4.7 & 642 & 1.7 & 1.4 & 1.9 & 113 & 2.7 & 1.7 & 4.31 & 145 & 2.0 & 1.6 & \\
\hline Unspecified & 4 & 18 & & - & - & - & 0 & - & - & - & 2 & 2.0 & 0.3 & 13.0 & 19 & 1.1 & 0.6 & 2.2 & & 15.3 & 2.1 & 111.7 & 0 & - & - & \\
\hline Cookin & & & & & & & & & & & & & & & & & & & & & & & & & & \\
\hline Electrica & 1079 & 1970 & 230 & 1.0 & Referent & & 60 & 1.0 & Referent & & 937 & 1.0 & Referent & & 1588 & 1.0 & Referent & & 104 & 1.0 & Referent & & 432 & 1.0 & Referent & \\
\hline $\begin{array}{l}\text { Non-electrical } \\
\chi^{2}(P \text { heterogeneity) }\end{array}$ & 300 & 703 & 103 & $\begin{array}{r}1.6 \\
10.1\end{array}$ & $\begin{array}{l}1.2 \\
(0.002)\end{array}$ & 2.2 & 30 & $\begin{array}{l}1.4 \\
1.6\end{array}$ & $\begin{array}{l}0.8 \\
(0.20)\end{array}$ & 2.2 & 390 & $\begin{array}{r}1.5 \\
19.4\end{array}$ & $\begin{array}{l}1.3 \\
(<0.0001)\end{array}$ & 1.9 & 1030 & $\begin{array}{r}1.6 \\
59.6\end{array}$ & $\begin{array}{l}1.4 \\
(<0.0001)\end{array}$ & 1.8 & 34 & $\begin{array}{l}1.2 \\
0.5\end{array}$ & $\begin{array}{l}0.8 \\
(0.47)\end{array}$ & 1.81 & 125 & $\begin{array}{l}0.8 \\
3.7\end{array}$ & $\begin{array}{l}0.6 \\
(0.05)\end{array}$ & \\
\hline Unspecified & 4 & 3 & 0 & - & - & - & 0 & - & - & - & 3 & 0.6 & 0.1 & 3.4 & 13 & 5.1 & 1.4 & 18.3 & 21 & 5.1 & 0.7 & 37.2 & 0 & - & - & \\
\hline Smokir & & & & & & & & & & & & & & & & & & & & & & & & & & \\
\hline $\mathrm{Ner}$ & 397 & 1662 & 11 & 1.0 & Referent & & 31 & 1.0 & Referent & & 113 & 1.0 & Referent & & 1178 & 1.0 & Referent & & 17 & 1.0 & Referent & & 326 & 1.0 & Referent & \\
\hline e/non-electrical & 131 & 60 & 5 & 1.4 & 0.5 & 4.0 & 15 & 1.3 & 0.7 & 2.4 & 63 & 1.6 & 1.1 & 2.4 & 782 & 1.6 & 1.4 & 1.8 & 8 & 1.5 & 0.6 & 3.6 & 86 & 0.7 & 0.5 & \\
\hline ee/electrical & 681 & 293 & 219 & 11.1 & & 20.8 & 29 & 4.3 & 2.5 & 7.3 & 824 & 3.9 & 3.1 & 5.0 & 399 & 1.7 & 1.4 & 2.0 & 87 & 3.0 & 1.8 & 5.2 & 106 & 1.8 & 1.4 & \\
\hline Ever smoke/non-electrical & 167 & 101 & 98 & $\begin{array}{r}20.1 \\
1178\end{array}$ & $\begin{array}{l}10.4 \\
(<00001)\end{array}$ & 38.9 & 15 & $\begin{array}{r}6.8 \\
446\end{array}$ & 3.5 & 13.4 & 326 & $\begin{array}{r}6.1 \\
880\end{array}$ & 4.6 & 8.2 & 241 & 2.7 & 2.1 & 3.5 & 26 & 3.6 & 1.8 & 7.0 & 39 & 1.9 & 1.3 & 2. \\
\hline $\begin{array}{l}\chi^{2}(P \text { trend }) \\
\text { Unspecified }\end{array}$ & 7 & 20 & 0 & - & - & - & 0 & - & - & - & 4 & & $\begin{array}{l}(<0 \\
0.5\end{array}$ & 7.5 & 31 & $\begin{array}{r}91.6 \\
2.0\end{array}$ & 1.1 & 3.6 & 21 & $\begin{array}{l}8.1 \\
15.8\end{array}$ & 4.0 & 62.1 & 0 & 17.9 & $1<0$ & \\
\hline
\end{tabular}

${ }^{a}$ Analyses adjusted for age, education, smoking status, and cooking fuel; odds ratios (OR) with $95 \%$ lower (LCI) and upper (UCl) confidence intervals presented. ${ }^{b}$ See Table I for disease groupings. ${ }^{c}$ Primarily hypertenstion (37\%), stroke (25\%) and congestive heart failure (18\%). ${ }^{\mathrm{d} C u r r e n t ~ s m o k e r s ~ i n c l u d e d ~ t h o s e ~ w h o ~ s m o k e d ~ w i t h i n ~} 5$ years of interview. ${ }^{\mathrm{e}}$ Non-electrical cooking fuel included wood, charcoal, coal, anthracite, parafin, and gas. 
Table 3 Risk of lung cancer, other smoking-related cancers, and cardiovascular disease distributed by smoking variables ${ }^{\mathrm{a}}$

\begin{tabular}{|c|c|c|c|c|c|c|c|c|c|c|c|c|c|c|c|c|c|c|c|c|c|c|c|c|c|c|}
\hline \multirow[b]{4}{*}{ Risk factor } & \multicolumn{2}{|c|}{ Controls $^{\mathrm{b}}$} & \multicolumn{8}{|c|}{ Lung cancer } & \multicolumn{8}{|c|}{ Smoking-related cancer ${ }^{b}$} & \multicolumn{8}{|c|}{ Cardiovascular disease $^{c}$} \\
\hline & \multirow{3}{*}{$\begin{array}{c}\text { Male } \\
n=1383 \\
n\end{array}$} & \multirow{3}{*}{$\begin{array}{c}\text { Female } \\
\begin{array}{c}n=2676 \\
n\end{array}\end{array}$} & \multicolumn{4}{|c|}{ Male } & \multicolumn{4}{|c|}{ Female } & \multicolumn{4}{|c|}{ Male } & \multicolumn{4}{|c|}{ Female } & \multicolumn{4}{|c|}{$n=159$} & \multicolumn{4}{|c|}{$95 \% \mathrm{Cl}$} \\
\hline & & & \multicolumn{2}{|c|}{$n=333$} & \multicolumn{2}{|c|}{$95 \% \mathrm{Cl}$} & \multicolumn{2}{|c|}{$n=90$} & \multicolumn{2}{|c|}{$95 \% \mathrm{Cl}$} & \multicolumn{2}{|c|}{$n=1330$} & \multicolumn{2}{|c|}{$95 \% \mathrm{Cl}$} & \multicolumn{2}{|c|}{$n=2631$} & $95 \% \mathrm{C}$ & & $n=1$ & 159 & $95 \% \mathrm{Cl}$ & & $n=5$ & 557 & $95 \% \mathrm{C}$ & \\
\hline & & & $n$ & OR & LCl & $\mathrm{UCl}$ & $n$ & OR & LCI & UCl & $n$ & OR & LCI & UCl & $n$ & OR & LCI & uCl & $n$ & OR & LCI & UCl & $n$ & OR & LCI & UCl \\
\hline Years smoked & & & & & & & & & & & & & & & & & & & & & & & & & & \\
\hline $\begin{array}{l}\text { Never smoked } \\
\text { Former smoker }\end{array}$ & 528 & 2264 & 16 & 1.0 & Referent & & 46 & 1.0 & Referent & & 176 & 1.0 & Referent & & 1970 & 1.0 & Referent & & 25 & 1.0 & Referent & & 412 & 1.0 & Referent & \\
\hline $1-20$ & 69 & 62 & 15 & 6.0 & 3.5 & 10.4 & 1 & 2.6 & 0.9 & 7.6 & 56 & 2.3 & 1.6 & 3.5 & 58 & 0.9 & 0.7 & 1.4 & 14 & 4.3 & 2.1 & 8.9 & 12 & $1.0 \mathrm{c}=\mathrm{s}$ & 0.6 & 2.0 \\
\hline $\begin{array}{l}21+ \\
\chi^{2}(P \text { trend })\end{array}$ & 53 & 32 & 22 & $\begin{array}{l}10.1 \\
49.1\end{array}$ & $\begin{array}{l}6.0 \\
(<0.000 \mathrm{I})\end{array}$ & 17.1 & 29 & $\begin{array}{l}2.0 \\
2.2\end{array}$ & $\begin{array}{l}0.4 \\
(0.13)\end{array}$ & 8.5 & 53 & $\begin{array}{r}2.8 \\
38.2\end{array}$ & $\begin{array}{l}1.8 \\
(<0.0001)\end{array}$ & 4.3 & 46 & $\begin{array}{l}1.5 \\
1.1\end{array}$ & $\begin{array}{l}1.0 \\
(0.29)\end{array}$ & 2.4 & 7 & $\begin{array}{r}4.9 \\
15.0\end{array}$ & $\begin{array}{l}1.9 \\
(<0.000 \mathrm{I})\end{array}$ & 12.5 & 10 & $\begin{array}{l}1.5 \\
1.3\end{array}$ & $\begin{array}{l}0.7 \\
(0.26)\end{array}$ & 3.1 \\
\hline Current smoker & & & & & & & & & & & & & & & & & & & & & & & & & & \\
\hline $1-20$ & 189 & 59 & 15 & 5.1 & 2.8 & 9.3 & 4 & 1.4 & 0.2 & 10.5 & 98 & 1.8 & 1.3 & 2.5 & 60 & 1.2 & 0.8 & 1.8 & 19 & 1.5 & 0.7 & 2.8 & 14 & 1.3 & 0.7 & 2.4 \\
\hline $\begin{array}{l}21+ \\
\chi^{2}(P \text { trend })\end{array}$ & 298 & 155 & 210 & $\begin{array}{r}20.1 \\
131.2\end{array}$ & $\begin{array}{l}\mid 4.9 \\
(<0.000 \mid)\end{array}$ & 27.2 & 2 & $\begin{array}{r}7.4 \\
59.2\end{array}$ & $\begin{array}{l}4.5 \\
(<0.0001)\end{array}$ & 12.3 & 6612 & $\begin{array}{r}6.1 \\
240.8\end{array}$ & $\begin{array}{l}4.9 \\
(<0.0001)\end{array}$ & 7.7 & 319 & $\begin{array}{r}2.1 \\
45.4\end{array}$ & $\begin{array}{l}1.7 \\
(<0.0001)\end{array}$ & 2.5 & 70 & $\begin{array}{r}5.5 \\
36.8\end{array}$ & $\begin{array}{l}3.2 \\
(<0.000 I)\end{array}$ & 9.2 & 47 & $\begin{array}{l}1.7 \\
8.4\end{array}$ & $\begin{array}{l}1.2 \\
(0.004)\end{array}$ & 2.3 \\
\hline Unspecified & 246 & 104 & 55 & 7.1 & 4.9 & 10.4 & 8 & 3.1 & 1.4 & 6.8 & 286 & 3.4 & 2.6 & 4.3 & 178 & 1.7 & 1.3 & 2.2 & 24 & 0.5 & 0.2 & 1.3 & 62 & 3.2 & 2.3 & 4.4 \\
\hline Tobacco/day ${ }^{\mathrm{d}}$ & & & & & & & & & & & & & & & & & & & & & & & & & & \\
\hline $\begin{array}{l}\text { Never Smoked } \\
\text { Former smoker }\end{array}$ & 528 & 2264 & 16 & 1.0 & Referent & & 46 & 1.0 & Referent & & 176 & 1.0 & Referent & & 1970 & 1.0 & Referent & & 25 & 1.0 & Referent & & 412 & 1.0 & Referent & \\
\hline $1-14 \mathrm{~g}$ & 243 & 137 & 45 & 5.4 & 3.0 & 9.8 & 11 & 2.9 & 1.5 & 5.8 & 197 & 2.3 & 1.7 & 2.9 & 203 & 1.5 & 1.2 & 1.9 & 15 & 1.5 & 0.7 & 2.9 & 63 & 2.4 & 1.7 & 3.3 \\
\hline $\begin{array}{l}15+g \\
\chi^{2}(P \text { trend }) \\
\text { Current smoker }\end{array}$ & 88 & 19 & 36 & $\begin{array}{l}11.7 \\
63.1\end{array}$ & $\begin{array}{l}6.2 \\
(<0.000 \text { I })\end{array}$ & 22.2 & 1 & $\begin{array}{l}2.0 \\
7.7\end{array}$ & $\begin{array}{l}0.3 \\
(0.006)\end{array}$ & 15.4 & 138 & $\begin{array}{r}4.1 \\
100.0\end{array}$ & $\begin{array}{l}3.0 \\
(<0.0001)\end{array}$ & 5.7 & 25 & $\begin{array}{r}1.3 \\
10.6\end{array}$ & $\begin{array}{l}0.7 \\
(0.001)\end{array}$ & 2.3 & 8 & $\begin{array}{l}2.1 \\
3.9\end{array}$ & $\begin{array}{l}0.9 \\
(0.05)\end{array}$ & 4.8 & 17 & $\begin{array}{r}4.8 \\
45.5\end{array}$ & $\begin{array}{l}2.5 \\
(<0.0001)\end{array}$ & 9.4 \\
\hline Current smoker & & & & & & & & & & & & & & & & & & & & & & & & & & \\
\hline $1-14 \mathrm{~g}$ & 405 & 202 & 113 & 10.4 & 6.0 & 18.0 & 23 & 5.3 & 3.1 & 9.0 & 554 & 4.1 & 3.3 & 5.1 & 353 & 1.8 & 1.5 & 2.2 & 61 & 2.9 & 1.8 & 4.7 & 49 & 1.3 & 1.0 & 1.9 \\
\hline $\begin{array}{l}15+g \\
\chi^{2}(P \text { trend })\end{array}$ & 95 & 20 & 115 & $\begin{array}{r}37.4 \\
183.5\end{array}$ & $\begin{array}{l}21.0 \\
(<0.000 \mathrm{I})\end{array}$ & 66.5 & 9 & $\begin{array}{l}18.5 \\
67.2\end{array}$ & $\begin{array}{l}7.7 \\
(<0.0001)\end{array}$ & 44.5 & 241 & $\begin{array}{r}6.8 \\
196.3\end{array}$ & $\begin{array}{l}5.1 \\
(<0.0001)\end{array}$ & 9.2 & 50 & $\begin{array}{r}2.6 \\
48.4\end{array}$ & $\begin{array}{l}1.5 \\
(<0.0001)\end{array}$ & 4.5 & 29 & $\begin{array}{r}6.1 \\
36.3\end{array}$ & $\begin{array}{l}3.4 \\
(<0.000 \mathrm{I})\end{array}$ & 11.1 & 14 & $\begin{array}{r}3.9 \\
13.1\end{array}$ & $\begin{array}{l}1.9 \\
(0.001)\end{array}$ & 7.8 \\
\hline Unspecified & 24 & 34 & 8 & 10.2 & 3.9 & 26.7 & 0 & - & - & - & 24 & 2.8 & 1.5 & 5.2 & 30 & 0.9 & 0.5 & 1.4 & 21 & 1.7 & 0.4 & 7.0 & 2 & 0.3 & 0.1 & 1.4 \\
\hline Pack years ${ }^{\mathrm{e}}$ & & & & & & & & & & & & & & & & & & & & & & & & & & \\
\hline $\begin{array}{l}\text { Never Smoked } \\
\text { Former smoker }\end{array}$ & 528 & 2264 & 16 & 1.0 & Referent & & 46 & 1.0 & Referent & & 176 & 1.0 & Referent & & 1970 & 1.0 & Referent & & 25 & 1.0 & Referent & & 412 & 1.0 & Referent & \\
\hline $1-10$ & 75 & 76 & 18 & 7.2 & 3.5 & 14.8 & 5 & 2.5 & 1.0 & 6.5 & 63 & 2.3 & 1.6 & 3.4 & 76 & 1.0 & 0.8 & 1.5 & 13 & 3.5 & 1.7 & 7.3 & 19 & 1.3 & 0.8 & 2.2 \\
\hline $11-20$ & 27 & 9 & 8 & 8.4 & 3.3 & 21.6 & I & 3.5 & 0.4 & 28.8 & 19 & 1.8 & 1.0 & 3.4 & 14 & 1.6 & 0.7 & 3.6 & 4 & 4.3 & 1.3 & 13.7 & 2 & 1.1 & 0.2 & 5.2 \\
\hline $\begin{array}{l}21+ \\
\chi^{2}(P \text { trend })\end{array}$ & 20 & 6 & 11 & $\begin{array}{l}15.8 \\
46.6\end{array}$ & $\begin{array}{l}6.4 \\
(<0.000 \mathrm{I})\end{array}$ & 38.7 & 0 & $\overline{2.3}$ & $\overline{-}(0.13)$ & - & 25 & $\begin{array}{r}3.4 \\
34.7\end{array}$ & $\begin{array}{l}1.8 \\
(<0.000 \mathrm{I})\end{array}$ & 6.3 & 13 & $\begin{array}{l}2.0 \\
2.5\end{array}$ & $\begin{array}{l}0.8 \\
(0.11)\end{array}$ & 5.4 & 4 & $\begin{array}{r}7.0 \\
16.6\end{array}$ & $\begin{array}{l}2.1 \\
(<0.000 \mathrm{I})\end{array}$ & 23.4 & 1 & $\begin{array}{l}0.9 \\
0.4\end{array}$ & $\begin{array}{l}0.1 \\
(0.52)\end{array}$ & 7.3 \\
\hline Current smoker & & & & & & & & & & & & & & & & & & & & & & & & & & \\
\hline $1-10$ & 257 & 140 & 48 & 8.1 & 4.4 & 14.7 & 9 & 3.4 & 1.6 & 7.1 & 257 & 3.3 & 2.6 & 4.2 & 198 & 1.5 & 1.2 & 1.9 & 44 & 3.0 & 1.7 & 5.1 & 35 & 1.4 & 0.9 & 2.1 \\
\hline $11-20$ & 117 & 51 & 46 & 11.6 & 6.3 & 21.4 & 9 & 7.0 & 3.2 & 15.3 & 215 & 4.9 & 3.7 & 6.6 & 107 & 2.1 & 1.5 & 3.0 & 15 & 2.3 & 1.2 & 4.7 & 10 & 1.1 & 0.5 & 2.1 \\
\hline $21-30$ & 64 & 9 & 42 & 18.8 & 9.9 & 35.7 & 7 & 30.0 & 10.3 & 87.6 & 126 & 5.3 & 3.7 & 7.5 & 44 & 5.1 & 2.5 & 10.5 & 6 & 2.1 & 0.8 & 5.3 & 7 & 4.0 & 1.5 & 10.7 \\
\hline $\begin{array}{l}31+ \\
\chi^{2}(P \text { trend })\end{array}$ & 41 & 12 & 85 & $\begin{array}{r}54.9 \\
190.0\end{array}$ & $\begin{array}{l}29.3 \\
(<0.000 \mathrm{I})\end{array}$ & 102.9 & 5 & $\begin{array}{l}13.0 \\
64.8\end{array}$ & $\begin{array}{l}4.3 \\
(<0.0001)\end{array}$ & 39.3 & 152 & $\begin{array}{r}9.5 \\
188.4\end{array}$ & $\begin{array}{l}6.4 \\
(<0.0001)\end{array}$ & 14.0 & 26 & $\begin{array}{r}2.2 \\
44.3\end{array}$ & $\begin{array}{l}1.1 \\
(<0.0001)\end{array}$ & 4.4 & 24 & $\begin{array}{l}17.8 \\
43.6\end{array}$ & $\begin{array}{l}8.8 \\
(<0.000 \mathrm{I})\end{array}$ & 35.9 & 9 & $\begin{array}{r}4.0 \\
14.4\end{array}$ & $\begin{array}{l}1.7 \\
(<0.0001)\end{array}$ & 9.7 \\
\hline Unspecified & 254 & 109 & 59 & 7.0 & 3.9 & 12.5 & 8 & 3.0 & 1.3 & 6.5 & 297 & 3.3 & 2.6 & 4.2 & 183 & 1.7 & 1.3 & 2.2 & 24 & 0.5 & 0.2 & 1.2 & 62 & 3.02 & 2.2 & 4.2 \\
\hline
\end{tabular}


A Cancer risk associated with smoking (current)

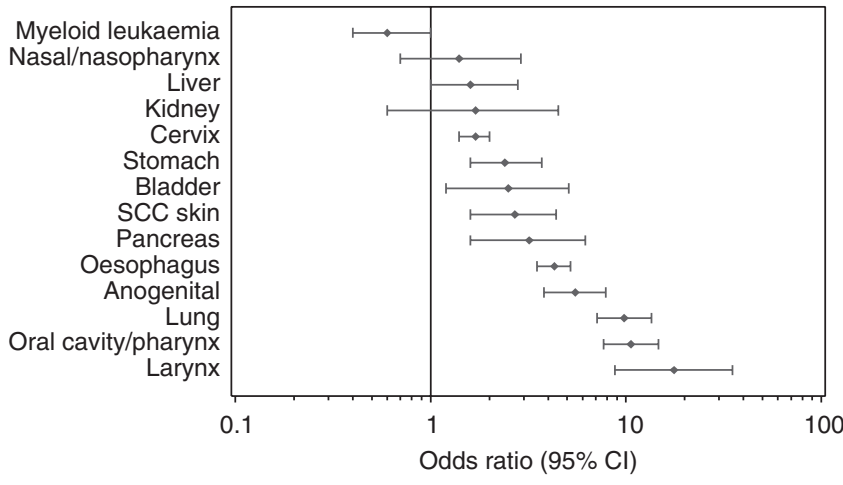

Referent $=$ never smokers; adjusts for age, gender, education, domestic fuel

B

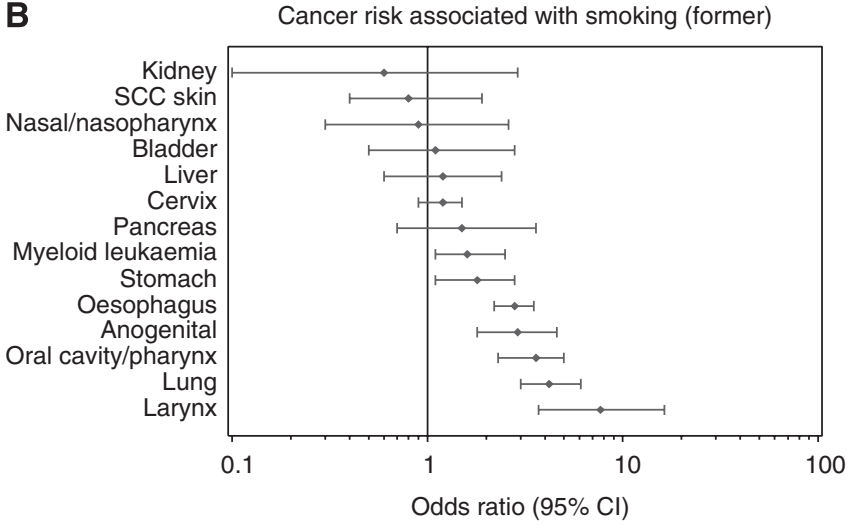

Referent $=$ never smokers; adjusts for age, gender, education, domestic fuel

Figure I Risks (ORs with 95\% Cls) among current $(\mathbf{A})$ and former (B) smokers for cancer at specific sites in comparison to never smokers. Adjusted for age, gender, education, alcohol consumption, and use of nonelectric cooking fuel.

smokers of more than 20 years had five times the risk of former smokers. There was a 3.5-fold increase in the risk of lung cancer between both men and women who smoked more than $15 \mathrm{~g}$ tobacco per day compared to those who smoked less. Furthermore, heavy smoking over a long period yielded a risk of lung cancer that was almost 55 times higher than that of never-smokers in men and 13 times higher in women. However, quitting for at least a 5-year period resulted in a two-fold lower risk of lung cancer overall. A similar pattern of results was found for the risks of smokingrelated cancers and cardiovascular disease, where there was a positive dose-response trend for both smoking duration and intensity and an inverse relationship with smoking cessation.

The larger sample size allowed for examination of rarer cancer types. After adjusting for age, gender, education, alcohol intake, and domestic cooking fuel, among current smokers the risk of cancers of the lung, larynx, oesophagus, stomach, pancreas, cervix, anogenital region, oral cavity/pharynx, and SCC skin were higher than among never smokers. The risk of all these cancers was lower among former smokers, however, remained significantly above that of never smokers for cancers of the larynx, lung, oesophagus, oral cavity/pharynx, anogenital region, and stomach. This trend was not apparent for myeloid leukaemia, where the association with smoking was significantly elevated among former smokers but not current smokers; as this is smoking related, it is probably a chance result that may disappear as more cases accrue (The International Agency for Research on Cancer (IARC, 2002)
Almost all of the cancers examined in this analysis were chosen, because they were identified as being partly caused by tobacco smoke in reports from the IARC working group (IARC, 2002; Vineis et al, 2004). However, in our study, the relative risk for cancers of the liver, kidney, bladder, and nasal cavity/nasopharynx were elevated but not significantly associated, perhaps because of the (1) small sample sizes; (2) shared exposures between cases and controls other than those used for adjustment (e.g., virus infection, diet, occupation, place of residence); or (3) within this particular population, smoking is not a risk factor for these cancer sites.

Evidence for a relationship of SCC of the skin and cancers of anogenital organs (other than cervix) with smoking remains sparse. A few studies have found smokers to be at a higher risk of cancers of the anus (Daling et al, 1992; Northfelt, 1996; Frisch et al, 1999; Tseng et al, 2003), vulva (Daling et al, 1992; Zarcone et al, 1997), and penis (Daling et al, 1992; Maden et al, 1993), but not of the vagina (Daling et al, 1992). In our study, current smokers were 4.3 (95\% confidence interval (CI), 2.9-6.4) times more likely than never smokers to have one of these cancers (including vaginal cancers). Studies on smoking and SCC skin have had mixed results (Aubry and MacGibbon, 1985; Karagas et al, 1992; Grodstein et al, 1995; Lear et al, 1998; De Hertog et al, 2001; Odenbro et al, 2005). Current smokers were also at 3.9 (95\% CI, 2.1-7.3) times the risk of SCC of the skin of never smokers, which is not dissimilar to estimates in other case-control studies where risks ranged from 2.3 to 3.3 (Aubry and MacGibbon, 1985; De Hertog et al, 2001). However, we did not adjust for sun exposure, a primary risk factor for SCC skin, and which is sometimes greater among smokers (De Hertog et al, 2001).

Cardiovascular disease showed a two-fold increased risk among smokers, which was approximately two-fold higher than nonsmokers; higher than that reported in a national study of tobaccorelated deaths (Sitas et al, 2004) and in other developing countries such as China (Liu et al, 1998). Our risks are similar to those observed in Western countries (Doll et al, 2004), although other risk factors for cardiovascular disease, such as diet, were not controlled for; a more comprehensive study incorporating these factors is needed.

The smoking-related risks estimated in this study are likely to be real in the black population of South Africa, as the prevalence of current smokers among controls (18\%) is comparable to that reported by the South African Demographic and Health Survey (SADHS) in 1998 (20.4\%) (Steyn et al, 2002) and in the All Media and Products Survey of the South African Advertising Research Foundation in 2000 (22.7\%) (van Walbeek, 2002a). Likewise, the prevalence of former smokers $(13 \%)$ in controls is similar to that in the SADHS study (6.2\% males and $10.3 \%$ females) (Steyn et al, 2002). However, because we used hospital-based controls, our risk estimates may slightly underestimate the real risks.

The smoking-related risks reported here also indicate the significant burden of disease from smoking in black South Africa, even though tobacco consumption is very low compared to developed countries. Of all 1998 adult deaths (aged >25), 8\% were attributed to smoking in an analysis of information on the death notification form (Sitas et al, 2004). Smoking prevalence may increase with the growth of the black middle class but is unlikely to reach the levels seen in developed countries in the past, due to peer attitudes and ever more stringent antitobacco legislation (Lopez et al, 1994). Case-control studies and analysis of the smoking questions on the national death notification form will allow the burden of tobacco-related disease to be monitored.

\section{ACKNOWLEDGEMENTS}

Srs. Gloria Mokwatle, Patricia Rapoho, and colleagues carried out the interviews. We thank the clinical staff of Johannesburg, Chris Hani Baragwanath and Hillbrow Hospitals for their assistance and

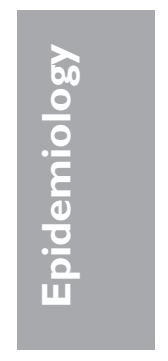


the patients for their participation. Thanks to Rajah Supramaniam for assistance with the figures. The Cancer Epidemiology Research Group at the National Health Laboratory Service is funded by the South African Medical Research Council, the (South African)

\section{REFERENCES}

Aubry F, MacGibbon B (1985) Risk factors of squamous cell carcinoma of the skin. A case-control study in the Montreal region. Cancer 55: $907-911$

Berrington dG, Urban M, Sitas F, Blackburn N, Hale M, Patel M, Ruff P, Sur R, Newton R, Beral V (2006) Antibodies against six human herpesviruses in relation to seven cancers in black South Africans: a case control study. Infect Agents Cancer 1: 2

Cohen AJ, Anderson HR, Ostro B, Pandey KD, Krzyzanowski M, Kunzli N, Gutschmidt K, Pope CA, Romieu I, Samet JM, Smith KR (2004) Urban air pollution. In Comparative Quantification of Health Risks: Global and Regional Burden of Disease Attribution to Selected Major Risk Factors, Ezzati M, Lopez A, Rodgers A, Murray CJL (eds), pp 1353-1433. World Health Organization: Geneva

Daling JR, Sherman KJ, Hislop TG, Maden C, Mandelson MT, Beckmann AM, Weiss NS (1992) Cigarette smoking and the risk of anogenital cancer. Am J Epidemiol 135: $180-189$

De Hertog SA, Wensveen CA, Bastiaens MT, Kielich CJ, Berkhout MJ, Westendorp RG, Vermeer BJ, Bouwes Bavinck JN (2001) Relation between smoking and skin cancer. J Clin Oncol 19: 231-238

Doll R, Peto R, Boreham J, Sutherland I (2004) Mortality in relation to smoking: 50 year's observations on male British doctors. BMJ 328: 1519

Frisch M, Glimelius B, Wohlfahrt J, Adami HO, Melbye M (1999) Tobacco smoking as a risk factor in anal carcinoma: an antiestrogenic mechanism? J Natl Cancer Inst 91: 708-715

Grodstein F, Speizer FE, Hunter DJ (1995) A prospective study of incident squamous cell carcinoma of the skin in the nurse's health study. J Natl Cancer Inst 87: 1061 - 1066

IARC (1985) IARC Monographs on the Evaluation of the Carcinogenic Risk of Chemicals to Humans. Lyon, France: World Health Organization International Agency for Research on Cancer

Karagas MR, Stukel TA, Greenberg ER, Baron JA, Mott LA, Stern RS (1992) Risk of subsequent basal cell carcinoma and squamous cell carcinoma of the skin among patients with prior skin cancer. Skin cancer prevention study group. J Am Med Assoc 267: 3305-3310

Lear JT, Tan BB, Smith AG, Jones PW, Heagerty AH, Strange RC, Fryer AA (1998) A comparison of risk factors for malignant melanoma, squamous cell carcinoma and basal cell carcinoma in the UK. Int J Clin Pract 52: $145-149$

Liu BQ, Peto R, Chen ZM, Boreham J, Wu YP, Li JY, Campbell TC, Chen JS (1998) Emerging tobacco hazards in China: 1. Retrospective proportional mortality study of one million deaths. BMJ 317: 1411-1422

Lopez A, Collishaw NE, Piha T (1994) A descriptive model of the cigarette epidemic in developed countries. Tob Control 3: 242-247

Maden C, Sherman KJ, Beckmann AM, Hislop TG, Teh CZ, Ashley RL, Daling JR (1993) History of circumcision, medical conditions, and sexual activity and risk of penile cancer. J Natl Cancer Inst 85: 19-24

Norman R, Mqoqi N, Sitas F (2006) Lifestyle-induced cancer in South Africa. In Chronic Diseases of Lifestlyles in South Africa. Technical Report, pp 142-185. Cape Town: South African Medical Research Council

Northfelt DW (1996) Anal neoplasia in persons with HIV infection. AIDS Clin Care 8: 63-66

Odenbro A, Bellocco R, Boffetta P, Lindelof B, Adami J (2005) Tobacco smoking, snuff dipping and the risk of cutaneous squamous cell
National Health Laboratory Service, and the University of the Witwatersrand. The Cancer Epidemiology Research Unit at The Cancer Council NSW is funded in the main by The Cancer Council New South Wales. carcinoma: a nationwide cohort study in Sweden. $\mathrm{Br} J$ Cancer 92: $1326-1328$

Pacella-Norman R, Urban MI, Sitas F, Carrara H, Sur R, Hale M, Ruff P, Patel M, Newton R, Bull D, Beral V (2002) Risk factors for oesophageal, lung, oral and laryngeal cancers in black South Africans. Br J Cancer 86: $1751-1756$

Saloojee Y (2006) Tobacco control in South Africa. In Chronic Diseases of Lifestyle in South Africa since 1995-2005. Technical Report, pp 48-57. Cape Town: South African Medical Research Council

Sitas F, Carrara H, Beral V, Newton R, Reeves G, Bull D, Jentsch U, PacellaNorman R, Bourboulia D, Whitby D, Boshoff C, Weiss R (1999) Antibodies against human herpesvirus 8 in black South African patients with cancer. $N$ Engl J Med 340: $1863-1871$

Sitas F, Pacella-Norman R, Carrara H, Patel M, Ruff P, Sur R, Jentsch U, Hale M, Rowji P, Saffer D, Connor M, Bull D, Newton R, Beral V (2000) The spectrum of HIV-1 related cancers in South Africa. Int J Cancer 88: $489-492$

Sitas F, Urban M, Bradshaw D, Kielkowski D, Bah S, Peto R (2004) Tobacco attributable deaths in South Africa. Tob Control 13: 396-399

Sitas F, Urban M, Stein L, Beral V, Ruff P, Hale M, Patel M, O'connell D, Yu XQ, Verzijden A, Marais D, Williamson AL (2007) The relationship between anti-HPV-16 IgG seropositivity and cancer of the cervix, anogenital organs, oral cavity and pharynx, oesophagus and prostate in a black South African population. Infect Agents Cancer 2: 6

Steyn K., Bradshaw D, Norman R, Laubscher R, Saloojee Y (2002) Tobacco use in South Africans during 1998: the first demographic and health survey. J Cardiovasc Risk 9: 161-170

The International Agency for Research on Cancer (2002) Tobacco Smoke and Involuntary Smoking. 83. Lyon, France: IARC. Ref Type: Report

Tseng HF, Morgenstern H, Mack TM, Peters RK (2003) Risk factors for anal cancer: results of a population-based case-control study. Cancer Causes Control 14: $837-846$

van Walbeek C (2002a) Recent trends in smoking prevalence in South Africa - some evidence from AMPS data. S Afr Med J 92: 468-472

van Walbeek C (2002b) The tobacco epidemic can be reversed: Tobacco control in South Africa During the 1990s. Applied Fiscal Research Centre, School of Economics, University of Cape Town: Cape Town (ISBN: 07992-2146-5)

Vineis P, Alavanja M, Buffler P, Fontham E, Franceschi S, Gao YT, Gupta PC, Hackshaw A, Matos E, Samet J, Sitas F, Smith J, Stayner L, Straif K, Thun MJ, Wichmann HE, Wu AH, Zaridze D, Peto R, Doll R (2004) Tobacco and cancer: recent epidemiological evidence. J Natl Cancer Inst 96: $99-106$

Wojcicki JM, Newton R, Urban M, Stein L, Hale M, Patel M, Ruff P, Sur R, Bourboulia D, Sitas F (2004) Low socioeconomic status and risk for infection with human herpesvirus 8 among HIV-1 negative, South African black cancer patients. Epidemiol Infect 132: $1191-1197$

Wojcicki JM, Newton R, Urban MI, Stein L, Hale M, Patel M, Ruff P, Sur R, Bourboulia D, Sitas F (2003) Risk factors for high anti-HHV-8 antibody titers ( $>$ or $=1: 51,200$ ) in black, HIV-1 negative South African cancer patients: a case control study. BMC Infect Dis 3: 21

Zarcone R, Mainini G, Carfora E, Cardone A (1997) Current etiopathogenetic views in vulvar cancer. Panminerva Med 39: $30-34$ 